\title{
Glt25d2 Knockout Directly Increases CD25+CD69- but Decreases CD25-CD69+ Subset Proliferation and is Involved in Concanavalin-Induced Hepatitis
}

\author{
Xiaohua Hao Ran Liu $^{\mathrm{a}}$ Yifan Zhang ${ }^{\mathrm{a}}$ Yufeng $\mathrm{Li}^{\mathrm{a}}$ Qun $\mathrm{He}^{\mathrm{b}}$ \\ Yubo Huang ${ }^{a}$ Yu Jiang ${ }^{c}$ Jiali Mac Ping Lic Hongshan Weic \\ alnstitute of Infectious Disease, Beijing Ditan Hospital, Capital Medical Univerisity, Beijing, 'Biochip \\ Center, the key laboratory of cell biology, Ministry of Education, College of Basic Medicine Science, \\ China Medical University, Shenyang, 'Department of Gastroenterology, Beijing Ditan Hospital, Capital \\ Medical Univerisity, Beijing, China
}

\section{Key Words}

$\mathrm{CD}^{+}{ }^{+}$T lymphocyte $\cdot$ Glycosylation $\cdot$ Proliferation $\bullet$ GLT25D2 $\bullet$ Gene knockout

\begin{abstract}
Background/Aims: The elaborate structure of the extracellular matrix (ECM) and the appropriate surface glycoforms upon it are indispensable to $\mathrm{CD}^{+} \mathrm{T}$ cell regulation. Methods: To explore the effects of Glc $1,2 \mathrm{Gal} \beta 1$ glycosylation mediated by GLT25D2 (Colgalt2) for CD4 ${ }^{+}$

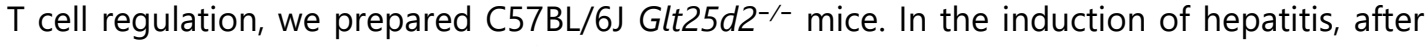
concanavalin A (Con A) challenge for 6,12 , and $24 \mathrm{~h}$, more extensive parenchymal injury was noted in Glt25d2-/- mice than in wild-type (WT) mice at $12 \mathrm{~h}$. Immunohistochemistry and laser scanning confocal microscopy were used to detect GLT25D2 expression, and subsets of CD4+T cells was analyzed by flow cytometry. A total of 26 cytokines in serum samples were determined using Luminex technology. Results: The trend in liver injury score variation was consistent with serum alanine aminotransferase and aspartate aminotransferase levels. The levels of interleukin 4 (IL-4), IL-1 $\beta$, IL-9, and several chemokines such as macrophage inflammatory protein-2, eotaxin, and growth-related oncogene $\alpha$ were significantly increased in Glt25 $\mathrm{d}^{-/-}$mice compared with WT mice after Con A challenge. A further phenotype analysis of primary Glt25d2-/- CD4 $4^{+}$cells showed that Glt25d2 knockout increased the frequency of the $\mathrm{CD} 25^{+} \mathrm{CD} 69^{-}$subset but decreased the frequency of the CD25-CD69+ subset after Con A challenge for 6,12 , and $24 \mathrm{~h}$ compared with those of WT CD4 ${ }^{+}$T cells. Activation-induced apoptosis was also significantly increased in Glt25 $\mathrm{d2}^{-l_{-}^{-}} \mathrm{CD} 4^{+} \mathrm{T}$ cells after Con A challenge compared with WT CD4 ${ }^{+} \mathrm{T}$ cells. Lectin microarray hybridization showed that Glt25d2 knockout increased the binding activity of Narcissus pseudonarcissus lectin to CD4 ${ }^{+} \mathrm{T}$ cells but

X. Hao and R. Liu contributed equally to this work.

\begin{tabular}{ll}
\hline Prof. Hongshan Wei & Department of Gastroenterology, Beijing Ditan Hospital, Capital Medical Univerisity \\
& No.8, Jinshun Eaststreet, Chaoyang District, 100015, Beijing (China) \\
& E-Mail drwei@ccmu.edu.cn
\end{tabular}
\end{abstract}


Amaranthus caudatus lectin-binding activity was lost during Con A challenge. Conclusion: The present results suggest that collagen glycosylation mediated by GLT25D2 may regulate a subset of $C D 4^{+} T$ cells and be involved in the pathogenesis of Con A-induced hepatitis.

(C) 2018 The Author(s)

Published by S. Karger AG, Basel

\section{Introduction}

Over the past half century, extracellular matrix (ECM) research has shown that matrix components play a fundamental role in immunity, including in immune cell development, effector regulation, and ligand-receptor interactions [1-3]. The function of T lymphocytes involved in an immune response is dependent on the precise matrix structure of the ECM. The dynamic variation of the ECM is indispensable for the migration and activation of effector T cells. Some ECM components, such as proteoglycans, can also act as signaling molecules, endogenous ligands of Toll-like receptors, activators of the innate immune response, and mediate activators of the adaptive immune response during inflammation $[4,5]$. The ECM can also modify major histocompatibility complex class II expression in the pathological state [6].

Collagen proteins are the most abundant components in the ECM, constituting $>30 \%$ of the total protein mass in multicellular organisms. Therefore, genetic defects of collagen formation affect almost every organ system and tissue throughout the body [7]. Among the genomes of vertebrates and higher invertebrates, 28 distinct collagen glycoproteins are encoded by at least 45 genes [8]. The primary structure of a collagen protein consists of GlyXaa-Yaa repeats and forms a left-handed polyproline II-like helix. Three glycopeptide chains align with an offset right-handed superhelix. Each peptide chain has at least one collagenous and one non-collagenous domain, variations of which depend on the specific collagen type [9].

After initiating translation, the pro-collagen peptide translocating into the endoplasmic reticulum (ER) is co-translationally modified by hydroxylation and glycosylation of lysine and hydroxylysine, respectively. Mature collagen molecules are modified by Glc $\alpha 1,2 \mathrm{Gal} \beta 1$ glycan on the hydroxylysine residue. The glycosylated levels of collagen proteins vary among tissues and organs. Since the first report nearly 60 years ago showed that collagen contains a galactose or glucosylgalactose 0-glycosidically linked to the hydroxylysine residue, it was of interest to explore which glycosyltransferase plays a critical role in this glycosylation process $[10,11]$. At the start of this century, lysyl hydroxylase 3 (EC 1.14.11.4) was found to possess the activities of galactosyltransferase (EC 2.4.1.50) and glucosyltransferase (EC 2.4.1.66) [12]. Schegg and colleagues recently reported that human collagen glycosylation is initiated by two $\beta(1-0)$ galactosyltransferases in vitro, specifically GLT25D1 (Colgalt1) and GLT25D2 (Colgalt2) [13].

In the ECM, the elaborate collagen structure is critical for coordinating lymphocyte homing, differentiation, and activation, as well as targeting migration [14, 15]. More importantly, some glycan components in the ECM may enhance T cell activation and trigger autoimmune inflammation [16]. Some collagen molecules, such as elastin peptides, can directly regulate immune responses in aging and age-related diseases [17]. In fact, peripheral $\mathrm{CD}^{+} \mathrm{T}$ cell activation was directly triggered by the ECM, as seen for those cells from mesenteric lymph nodes in vivo [18]. These results suggested that the glycan structure of collagen plays an important role in T lymphocyte regulation, but as far as we have seen, no relevant data are available. Consequently, the elucidation of the interaction between collagen glycosylation and lymphocyte regulation is essential for generating effective immunotherapies.

Many components of the ECM are correlated with $\mathrm{CD} 4^{+} \mathrm{T}$ lymphocyte regulation, such as laminins [19], proteoglycan aggrecans [20], and integrin [21, 22]. The co-culturing of CD4+ $\mathrm{T}$ cells with fibroblasts significantly increased the secretion of IL-17 and other cytokines [23]. These results suggested that the ECM and its elaborate construction is indispensable to the functional regulation of $\mathrm{CD} 4^{+} \mathrm{T}$ lymphocytes. As a major component of the ECM, its extent and pattern of glycosylation directly regulate cross-link maturation in fibrillar collagen [24, 
25]. More importantly, almost all ECM components are glycoproteins since these components require trafficking from a secretory pathway (from the ER to the Golgi complex) to the ECM. $\mathrm{CD} 4^{+} \mathrm{T}$ regulation may be dependent on collagen glycosylation to some degree. As far as we have seen, there is currently no evidence available to answer this question.

To address this question, we recently prepared a Glt25d2-knockout (Glt25d2/-) mouse model [26]. The intravenous injection of concanavalin A (Con A) is a widely used model for acute immune-mediated hepatitis in mice [27]. Since CD4 ${ }^{+} \mathrm{T}$ lymphocytes as well as NKT cells are the major effector cells involved in Con A hepatitis [28], the Con A-induced hepatitis model was chosen to elucidate the role of $\mathrm{CD} 4^{+} \mathrm{T}$ cells in Glt25d2/- mice. CD25 and CD69 are activation markers of T lymphocytes [29]. The emergence of CD25 molecules can occur if $\mathrm{CD}^{+} \mathrm{T}$ cells are activated and proliferating [30]. As the best-characterized populations of regulatory $\mathrm{T}$ cells, $\mathrm{CD} 4^{+} \mathrm{CD} 25^{+} \mathrm{T}$ cells have important roles in maintaining normal homeostasis and play a crucial role in infectious and degenerative diseases [31].

Our present results suggest that Glt25d2 knockout regulates the subset frequency of $\mathrm{CD}^{+} \mathrm{T}$ cells and is involved in the pathogenesis of Con A-induced hepatitis.

\section{Materials and Methods}

Preparation of Glt25d2-/- mice and ethics statement

To elucidate the role of GLT25D2 in liver injury, we recently prepared Glt25d2/- mice using a genetargeting method [26]. The sense primer (loxp-F) 5'-ATGTCCTGTCTAGTGTGGTCC-3' and antisense primer (Loxp-R) 5' - agggagttgtgcgaatctat-3' were used to genotype the wild-type (WT) and Glt25d2-/- mice. Western blotting was used to further confirm Glt25d2 knockout (polyclonal anti-GLT25D2; Abcam, Cambridge, UK).

The experimental mice were raised in the Animal Center of Peking University Health Science Center according to the National Institutes of Health Guide for the Care and Use of Laboratory Animals. This study was approved by the Experimental Animal Care and Use Committee of Peking University Health Science Center.

\section{Animals and hepatitis model}

To create the Con A-induced hepatitis model, male mice (6-8 weeks old) were used in this experiment [27]. Specific-pathogen-free WT $\left(\right.$ Glt25d2 $\left.{ }^{+/+}\right)$C57BL/6J mice (Animal Center of Peking University Health Science Center, Beijing, China) were used as control animals. Each was maintained in a specific-pathogenfree condition at the Animal Center of Peking University Health Science Center. All experimental mice were housed under standard conditions $\left(22-24^{\circ} \mathrm{C}\right)$ with a light-dark cycle of 12:12 h. Sterile water and food were available ad libitum. The hepatitis model was induced by an intravenous injection of $10 \mathrm{mg} / \mathrm{kg}$ Con A (SigmaAldrich, St. Louis, MO) and the liver injury was assessed before and 6, 12, and $24 \mathrm{~h}$ after Con A administration. The liver injury was assessed as serum levels of alanine aminotransferase (ALT) and aspartate aminotransferase (AST). The injury score was used to evaluate the hepatic tissue staging as previously reported [32]. The study design is shown in Fig. 1.

Immunohistochemistry and laser scanning confocal microscopy

After the mice were sacrificed, the liver and spleen tissues were obtained at different time points after Con A injection. The tissues were fixed with 10\% formaldehyde, embedded in paraffin, and cut into $3-$ to $5-\mu \mathrm{m}$ sections. Hematoxylin and eosin (H\&E) staining was used to evaluate liver injury grade. After

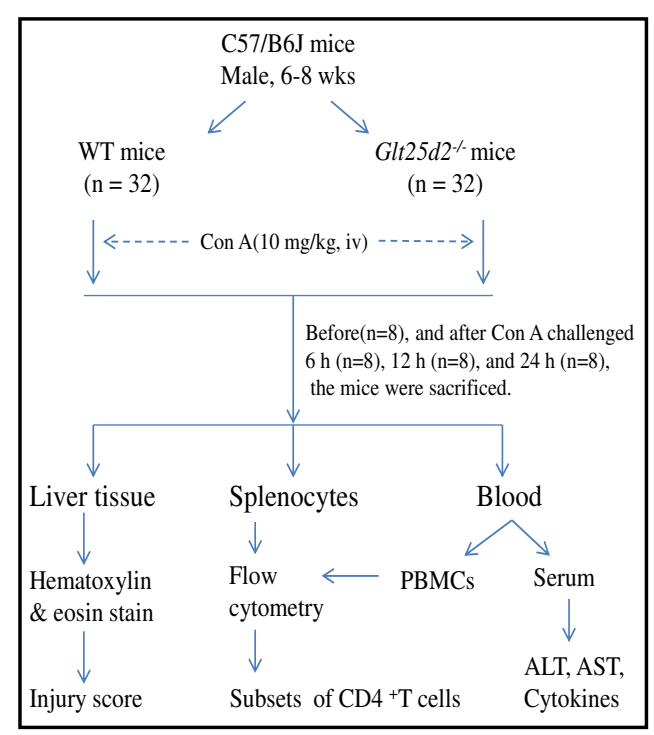

Fig. 1. Study design (in vivo). 
antigen retrieval was completed in sodium citrate buffer ( $\mathrm{pH} 6.0$ for $10 \mathrm{~min}$ ), the endogenous peroxidase was blocked for $5 \mathrm{~min}$. Sections were incubated for $1 \mathrm{~h}$ at room temperature with anti-GLT25D2 antibody (1:500). After incubation with the secondary horseradish peroxidase-conjugated immunoglobulin G, DAB chromogen was used to detect GLT25D2 expression in the hepatic and splenic tissues.

We subcloned the coding sequence of Glt25d2 into the pDSRED-N1 plasmid. The pDSRED-Glt25d2-N1 plasmid was then transfected into HSC-T6 cells to express GLT25D2 recombinant protein with red fluorescence. The coding sequence of the ER-Golgi intermediate compartment 53 (ERGIC53) protein $[33,34]$ was subcloned into the pEGFP-C1 plasmid to construct the pEGFP-ERgic53-C1 plasmid, which expresses recombinant ERGIC53 protein with green fluorescence. DAPI staining was performed $48 \mathrm{~h}$ after co-transfection of the pDSRED-Glt25d2-N1 and pEGFP-ERgic53-C1 plasmids into HSC-T6 cells. Confocal laser scanning microscopy (Zeiss LSM 510, Oberkochen, Germany) was used to analyze the GLT25D2 and ERGIC53 expression in the HSC-T6 cells.

Flow cytometry analysis of $\mathrm{CD} 4^{+}$subsets in peripheral blood mononuclear cells and splenocytes

To detect surface markers of $\mathrm{CD} 4^{+} \mathrm{T}$ cells, peripheral blood mononuclear cells and splenocytes were stained with CD4-APC, CD8-perCP, CD25-PE, and CD69-FITC antibodies (eBioscience, San Diego, CA) and incubated for $20 \mathrm{~min}$ at $4^{\circ} \mathrm{C}$ in the dark. After washing, we performed flow cytometry analysis (FACSCalibur flow cytometer; BD Biosciences, San Jose, CA) of the $\mathrm{CD} 4^{+} \mathrm{T}$ cell subsets. At least 10, 000 live events were accumulated through forward- and side-scatter parameters. CellQuest Pro software (BD Biosciences) was used to analyze the flow cytometry data.

\section{Primary $C D 4^{+} T$ cell proliferation and apoptosis in vitro}

Splenocytes were harvested from the WT and Glt25d2/- mice by dissociation through a $0.45-\mu \mathrm{m}$ wire mesh. After lysing erythrocytes using ammonium chloride, the cells were subsequently resuspended in complete RPMI 1640 media containing 10\% fetal calf serum, L-glutamine, penicillin, and streptomycin. To isolate the $\mathrm{CD}^{+} \mathrm{T}$ cells, the magnetic bead sorting technique (EasySep Mouse $\mathrm{CD} 4^{+} \mathrm{T}$ Cell Isolation Kit; Miltenyi Biotec, Bergisch Gladbach, Germany) was used. Briefly, splenocytes were incubated with anti-CD4 microbeads for $15 \mathrm{~min}$ at $4^{\circ} \mathrm{C}$ following the manufacturer's instructions. After washing with PBEB buffer (phosphate buffered saline [PBS], 0.5\% bovine serum albumin, $5 \mathrm{mM}$ ethylenediaminetetraacetic acid), the $\mathrm{CD} 4^{+} \mathrm{T}$ cells were eluted from the LS columns and resuspended in RPMI 1640 media. After culturing in RPMI 1640 media for $12 \mathrm{~h}$, the $\mathrm{CD} 4^{+} \mathrm{T}$ cells were treated with Con A (5 $\left.\mu \mathrm{g} / \mathrm{mL}\right)$ for another 6,12 , or $24 \mathrm{~h}$. For the subset analysis, $\mathrm{CD} 4^{+} \mathrm{T}$ cells from the WT and $\mathrm{Glt} 25 \mathrm{~d} 2^{-/-}$mice were incubated with fluorescently tagged antibodies against CD4, CD8, CD25, and CD69 (eBioscience) for $30 \mathrm{~min}$ at room temperature in the dark. Before the analysis, the stained $\mathrm{CD} 4^{+} \mathrm{T}$ cells were washed with cold PBS.

For the apoptosis evaluation, the CD4 $4^{+} \mathrm{T}$ cells from the WT and $G l t 25 d 2^{---}$mice were incubated in medium containing Con A for $0,6,12$, or 24

$h$. The cells were labeled with an apoptosis marker (Annexin V, 7-AAD) for the subset analysis. Briefly, after being labeled with CD4 antibody, the cells were washed with PBS and resuspended in binding buffer. After anti-Annexin $\mathrm{V}$ fluorescently tagged antibody and 7-AAD were added, the $\mathrm{CD} 4^{+} \mathrm{T}$ cells were incubated for $10 \mathrm{~min}$ in the dark at $37^{\circ} \mathrm{C}$. Apoptosis was calculated as the percentage of 7-AAD ${ }^{+}$and Annexin $\mathrm{V}^{+}$cells.

\section{Cytokine determination}

A total of 26 cytokines in serum samples were determined using Luminex technology with Milliplex detection kits (Millipore, Burlington, MA) according to the manufacturer's protocols. Those cytokines included interleukins and nine chemokines.

Table 1. Lectin spot microarray used in this study

\begin{tabular}{lcc}
\hline Lectin location No. on array & Lectin names & abbreviation \\
\hline 1 & Lotus tetragonolobus lectin & LTL \\
2 & Pisum sativum agglutinin & PSA \\
3 & Lens culinaris agglutinin & LCA \\
4 & Ulex europaeus lectin type 1, & UEA-1 \\
5 & Aurentia lectin & AAL \\
6 & Maackia amurensis lectin I & MAL-I \\
7 & Maackia amurensis lectin II & MAL-II \\
8 & Sambucus nigra & SNA \\
9 & Wheat germ agglutinin & WGA \\
10 & Erythrina cristagalli lectin & ECL \\
11 & Datura stramonium agglutinin & DSA \\
12 & Solanum tuberosum lectin & STL \\
13 & Succinylated WGA & SWGA \\
14 & Helix pomatia agglutinin & HPA \\
15 & Canavalia ensiformis & ConA \\
16 & Galanthus nivalis agglutinin & GNA \\
17 & Hippeastrum hybrid lectin & HHL \\
18 & Bauhinia purpurea lectin & BPL \\
19 & Euonymus europaeus lectin & EEL \\
20 & Jackfruit lectin & Jacalin \\
21 & Wisteria floribunda lectin & WFA \\
22 & Amaranthus caudatus lectin, & ACL \\
23 & Maclura pomifera lectin & MPL \\
24 & Dolichos biflorus agglutinin & DBA \\
25 & Soybean agglutinin & SBA \\
26 & & NPL \\
\hline
\end{tabular}




\section{Lectin microarray and hybridization}

The lectin microarray was prepared as previously described [35, 36]. Briefly, lectins (Vector Laboratories, Inc., Burlingame, CA) (Table 1) were dissolved in spotting solution at a concentration of $1 \mathrm{mg} /$ $\mathrm{mL}$ (Sambucus nigra leptin, MAL-I, and MAL-II) or $0.5 \mathrm{mg} / \mathrm{mL}$ (other lectins) and spotted in duplicate onto a 3-glycidoxypropyltrimethoxysilane glass slide using a microarray printing robot (MicroGridII; BioRobotics Ltd., Cambridge, UK). After being spotted, washed, and incubated, the slides were blocked with 1\% bovine serum albumin. Purified CD4 ${ }^{+} \mathrm{T}$ cells from the spleens of WT and Glt25d2/- mice were cultured in RPMI 1640 media. Before and after Con A treatment for 6, 12, or $24 \mathrm{~h}$, the harvested CD4+ $\mathrm{T}$ cells were suspended in PBS and allowed to bind to lectin microarrays at $37^{\circ} \mathrm{C}$ for $30 \mathrm{~min}$. The unbound $\mathrm{CD} 4^{+} \mathrm{T}$ cells were washed with cold PBS. The bound CD4+ $\mathrm{T}$ cells immobilized on the glass slides were stained with $\mathrm{H} \& \mathrm{E}$ and observed by microscopy.

\section{Statistical analysis}

The quantitative results are represented as the mean \pm SEM. Intergroup differences were tested using Student's $t$ test or the Mann-Whitney $U$ test. Differences among multiple groups were analyzed using oneway analysis of variance. Statistical significance was defined as values of $P<0.05$. These analyses were performed using GraphPad Prism version 5.01 software.

\section{Results}

GLT25D2 expressed in hepatic and splenic tissues

Using our previously prepared Glt25 $\mathrm{d}^{-/-}$mice, we first confirmed the genotype and phenotype using polymerase chain reaction (Fig. 2A) and western blotting (Fig. 2B), respectively. We further evaluated GLT25D2 expression in the hepatic and splenic tissues of WT and Glt25d2/- mice by immunohistochemical (IHC) staining. As we speculated, there was no GLT25D2 protein expression in the tissues of the Glt25 $2^{-/-}$mice; however, IHC staining revealed that the GLT25D2 protein was expressed in the hepatic and splenic tissues of WT mice (Fig. 2C-E).

\section{GLT25D2 expressed in hepatic and splenic tissues}

The C-terminus of GLT25D2 contains the RDEL motif, an ER retrieval signal, suggesting that it is a resident protein in the ER according to a recent report [36]. The confocal laser scanning microscopy images show that GLT25D2 protein and ERGIC53 protein were colocalized in the ER (Fig. 2F).

\section{Glt25d2 knockout aggravates liver injury}

We first determined whether GLT25D2 was involved in Con A-induced liver injury. Con A $(10 \mathrm{mg} / \mathrm{kg})$ was injected into healthy WT mice and Glt25 $\mathrm{d}^{-/-}$mice to prepare the Con Ainduced hepatitis model. H\&E staining showed that Con A administration resulted in more extensive hepatocellular damage in Glt25 $\mathrm{d}^{-/-}$mice than in WT mice, as represented by the presence of a severely collapsing liver plate (Fig. 3). The liver injury scores of Glt25d2/- mice were increased after Con A challenge for $12 \mathrm{~h}(3.5 \pm 0.45 ; P=0.02)$ compared with those of Glt25d2 $2^{--}$mice after $12 \mathrm{~h}(2.88 \pm 0.44)$. However, there was no difference in injury scores between Glt25d2 $2^{--}$and WT mice after Con A challenge for 6 or $24 \mathrm{~h}(1.71 \pm 0.49, P=0.32$; $3.58 \pm 0.49$ vs $3.50 \pm 0.44, P=0.71$, respectively). This variation trend was consistent with the serum ALT and AST levels. Although those mice were raised in the same conditions, the ALT levels $(58.83 \pm 15.28 \mathrm{U} / \mathrm{L})$ of the Glt25 $\mathrm{d}^{-/-}$mice were significantly higher than those of the WT mice ( $43.38 \pm 10.54 \mathrm{U} / \mathrm{L}, P=0.04$ ) at baseline. After Con A administration for $6 \mathrm{~h}$ $(6738.0 \pm 3524.0 \mathrm{U} / \mathrm{L}$ vs $2101 \pm 1811 \mathrm{U} / \mathrm{L}, P=0.01)$ or $12 \mathrm{~h}(15060.0 \pm 8052.0 \mathrm{U} / \mathrm{L}$ vs 7041.0 $\pm 2056 \mathrm{U} / \mathrm{L}, P=0.02$ ), this difference was more significant (Fig. 3). The same variation trend was also observed in serum AST levels before and after Con A challenge between WT and Glt25d2/- mice (Fig. 3). 


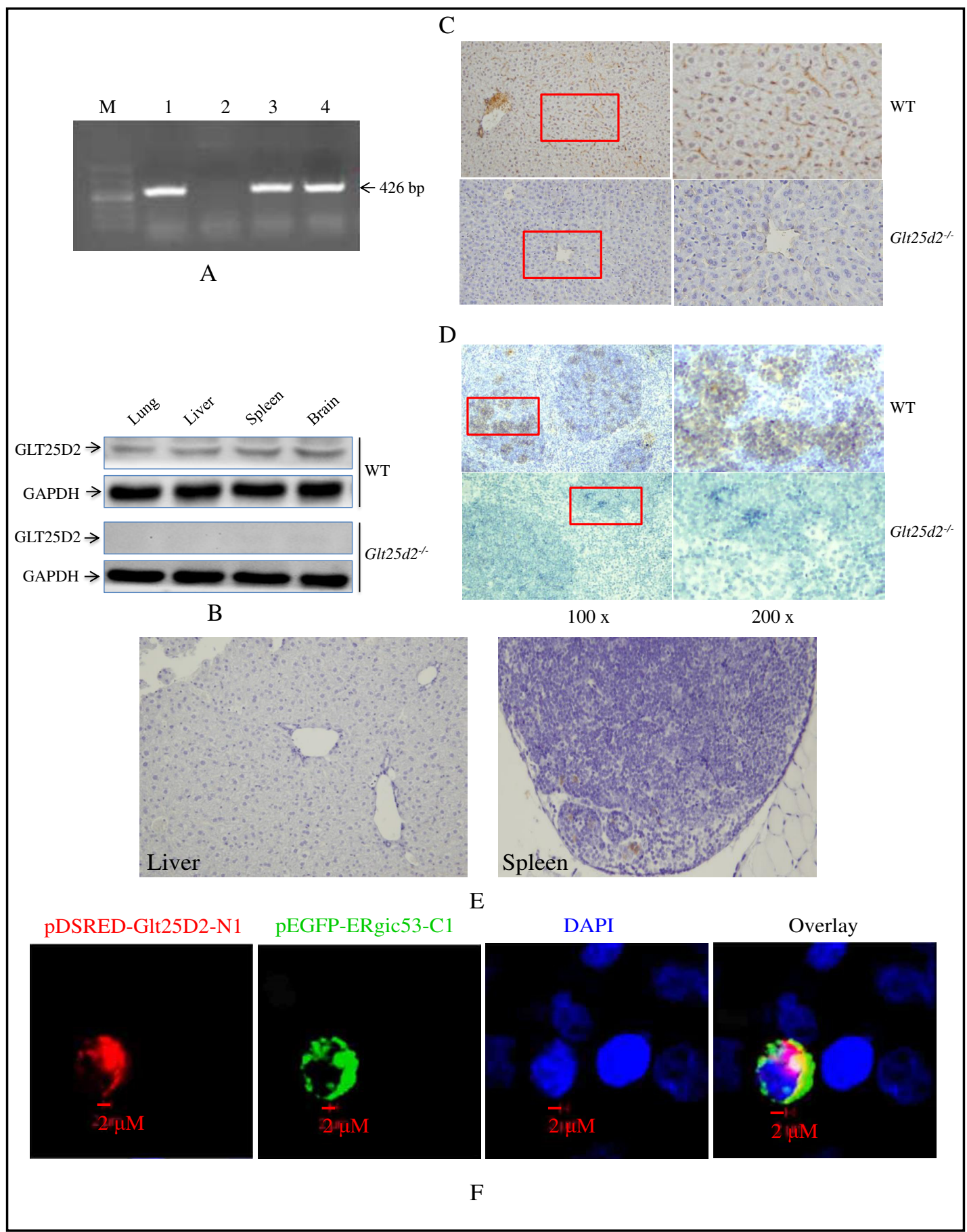

Fig. 2. Immunohistochemical staining of GLT25D2 expression in hepatic and splenic tissues. A, GLT25D2 protein in the hepatic tissue of wild-type mice was mainly expressed in the interstitial region. B, Major expression was seen in the germinal center of splenic tissue, whereas no expression was seen in the hepatic and splenic tissues of Glt25d2/-- mice. C, GLT25D2 protein was expressed in the hepatic tissues of WT mice. D, GLT25D2 protein was expressed in the splenic tissues of WT mice. E, Isotype control liver and spleen tissue. F, Confocal laser scanning microscopy images show that GLT25D2 and ERGIC53 proteins were colocalized in the endoplasmic reticulum. 


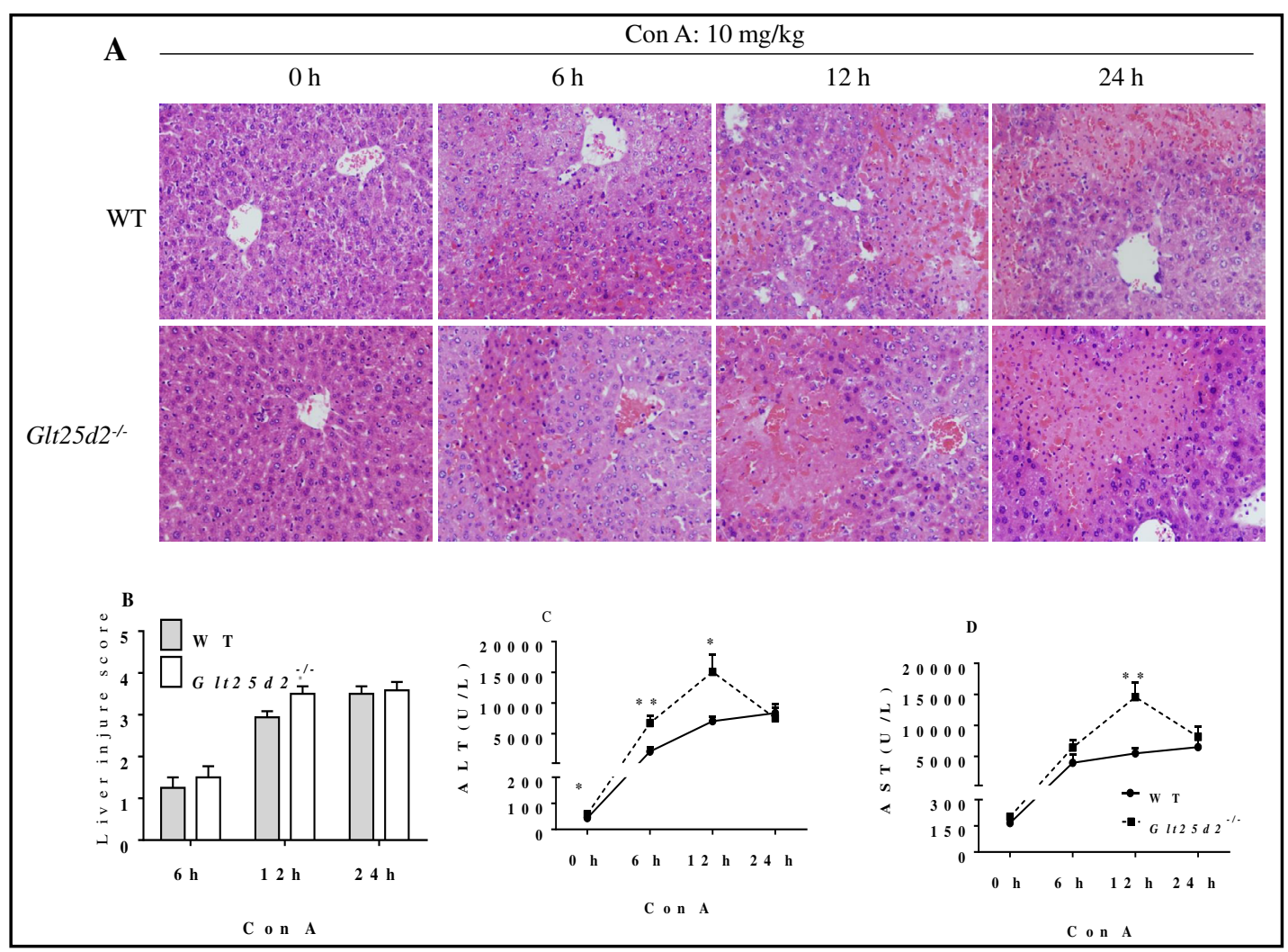

Fig. 3. Liver injury score and serum biochemical analysis. A, Hematoxylin and eosin staining of hepatic tissue $(\times 200)$. After concanavalin A (Con A) administration for 6, 12, or $24 \mathrm{~h}$, centrilobular hemorrhagic necrosis was seen in the hepatic tissue. The injury score for lobular inflammation was as reported previously [50]. $\mathrm{B}$, Compared with tissues of wild-type mice, more intensive necrosis was visible in the Glt25d2/- mouse hepatic tissue after Con A challenge for $12 \mathrm{~h}$. C, D, Alanine aminotransferase and aspartate transferase levels varied before and after Con A challenge for $0,6,12$, or $24 \mathrm{~h}\left({ }^{*} \mathrm{P}<0.05\right.$; $\left.{ }^{* *} \mathrm{P}<0.01\right)$.

\section{Different cytokine profiles between WT and Glt25d2/- mice}

To characterize the inflammatory response more completely between WT and Glt25d2-/mice, we performed Luminex analysis of the serum. After Con A challenge for $6 \mathrm{~h}(25.79 \pm$ $4.32 \mathrm{pg} / \mathrm{mL})$ or $12 \mathrm{~h}(18.43 \pm 4.41 \mathrm{pg} / \mathrm{mL})$, the serum IL-1 $\beta$ levels of the Glt25d2/- mice were markedly increased compared with those of the WT mice $(17.5 \pm 3.9 \mathrm{pg} / \mathrm{mL}, P=0.002$; and $10.43 \pm 2.79 \mathrm{pg} / \mathrm{mL}, P=0.003$ ). After Con A challenge for 6,12 , or $24 \mathrm{~h}$, the levels of IL-4, IL6 , and IL-9 were also significantly increased in Glt25 $\mathrm{d}^{-/-}$mice compared with those in WT mice (Fig. 4). This trend was also observed with some chemokines, including macrophage inflammatory protein 2 (MIP-2), eotaxin, and growth-related oncogene $\alpha$ (GRO $\alpha$ ) (Fig. 4). The notable result is the serum IL-9 level. After Con A administration for 6, 12, and $24 \mathrm{~h}$, the serum IL-9 level was decreased in WT mice but significantly increased in Glt25d2-/- mice after Con A challenge for $12 \mathrm{~h}(19.09 \pm 11.54 \mathrm{pg} / \mathrm{mL}$ vs $7.82 \pm 5.26 \mathrm{pg} / \mathrm{mL}, P=0.02)$. No differences in serum levels of other cytokines were observed between WT and Glt25d2-/mice, such as IL-17, IL-23, IL-27, IL 12p70, MCP-3, MIP-1a, MIP-1b, and RANTES (data not shown).

\section{Phenotype analysis of blood and splenic subsets of CD4+ $T$ cells}

To investigate whether proliferation in $\mathrm{CD}^{+} \mathrm{T}$ cell subsets plays a role in Con A-induced liver injury, we studied the characteristics of $\mathrm{CD} 4^{+} \mathrm{T}$ cell subsets of Con A-challenged mice. Con A administration induced a significant decrease in the frequency of the CD2 $5^{+} \mathrm{CD} 69^{+}$ subset in the blood of Glt25d2/- mice $(17.85 \% \pm 5.52 \%$ vs $33.24 \% \pm 3.96 \%, P<0.0001) 12$ 
Fig. 4. Serum c y to ki n e s before and after concanavalin A challenge. L u m i n e $x$ technology was used to determine the serum levels of 26 cytokines ( $* \mathrm{P}<0.05$; $* * \mathrm{P}<0.01$; $* * * \mathrm{P}<0.001)$.
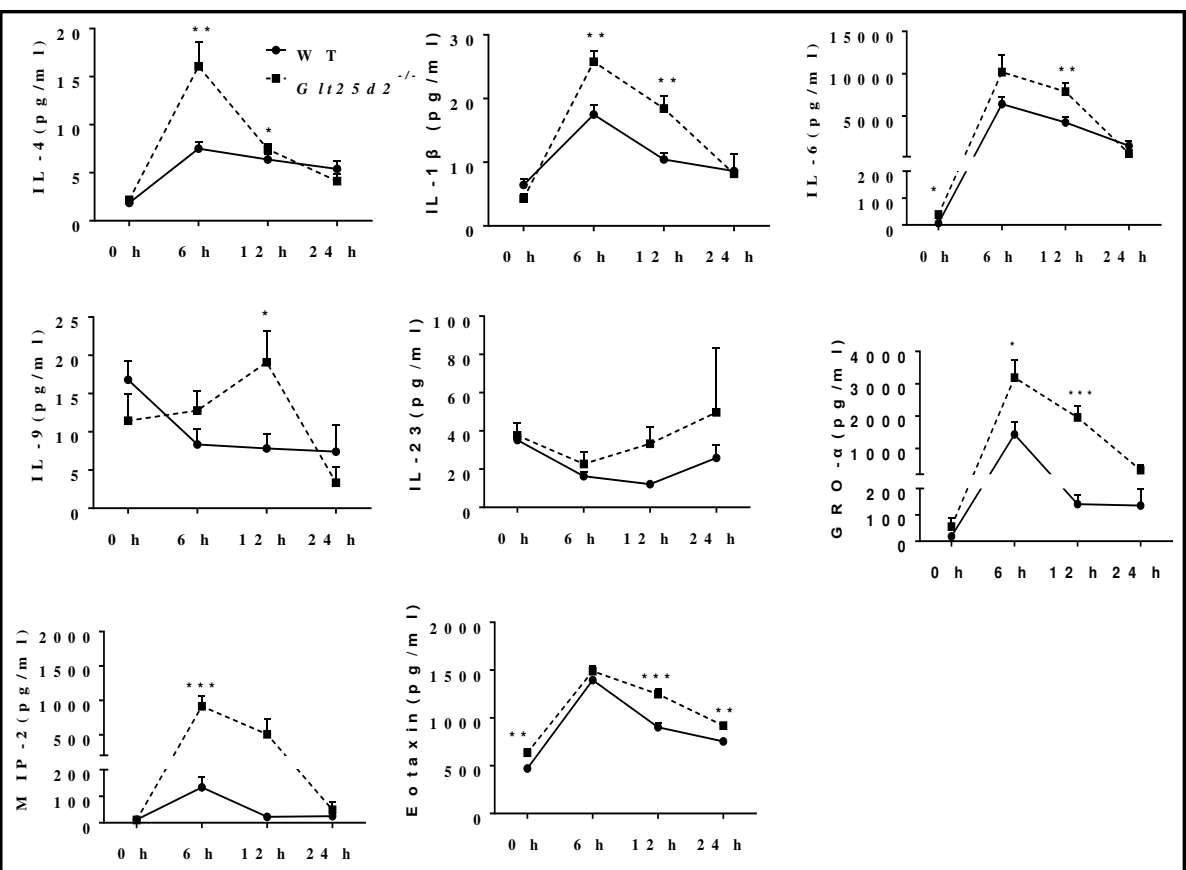

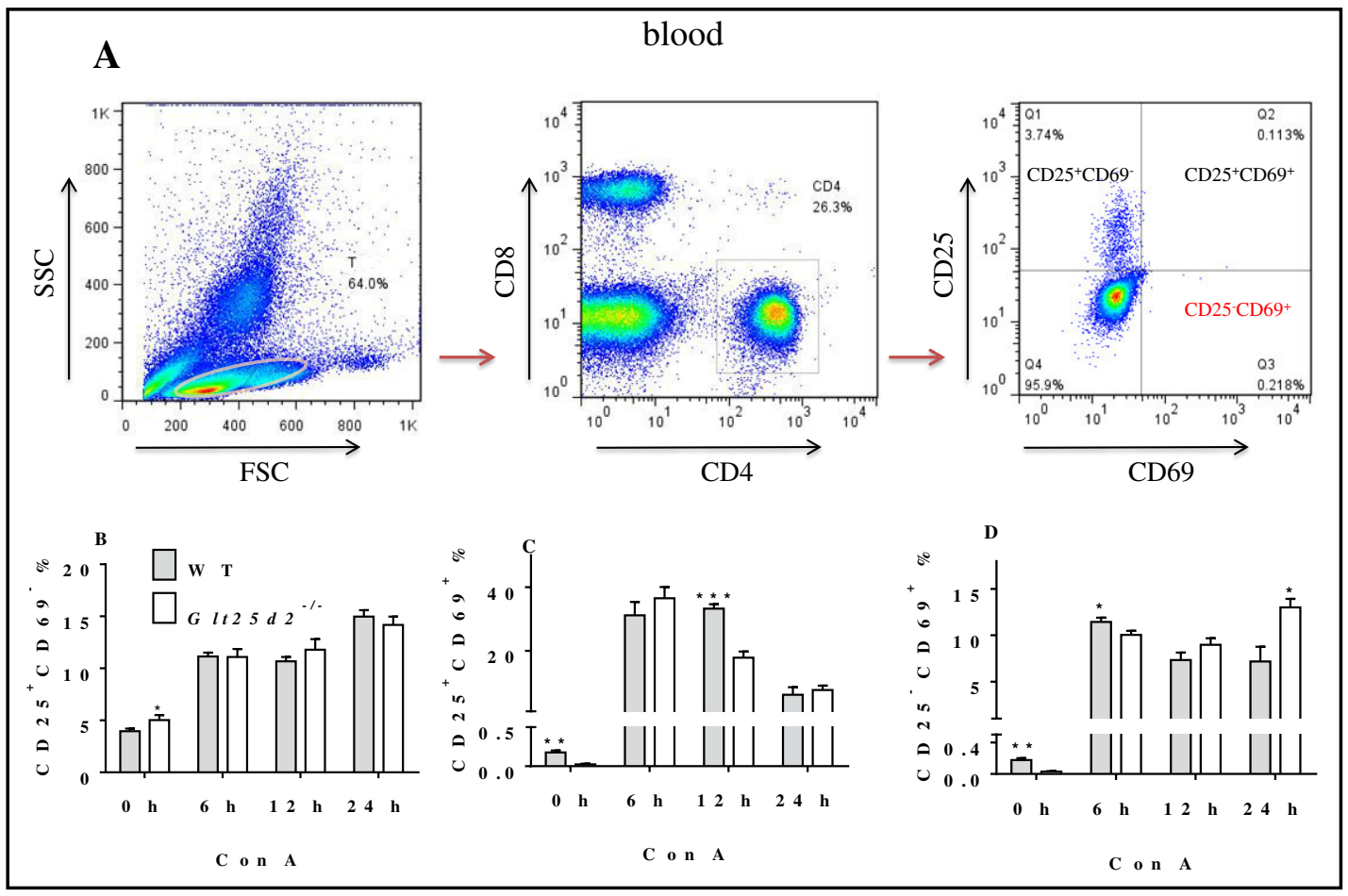

Fig. 5. Phenotype analysis of blood subsets of $\mathrm{CD} 4^{+} \mathrm{T}$ cells. A, Gating method used to identify CD4+T cells and their subsets. B-D, The column diagram shows CD25+CD69- (B), CD25+CD69+ (C), and CD25-CD69+ (D) subsets of $\mathrm{CD}^{+}{ }^{+} \mathrm{T}$ cells in the blood before and after concanavalin A challenge for $0,6,12$, or $24 \mathrm{~h}$.

$\mathrm{h}$ after challenge, but the frequency of the $\mathrm{CD} 25^{-} \mathrm{CD} 69^{+}$subset was markedly increased at $24 \mathrm{~h}(13.02 \% \pm 2.06 \%$ vs $7.17 \% \pm 3.55 \%, P=0.01)$ compared with those of WT mice (Fig. $5)$. Interestingly, the increased frequency of the CD25+CD69- subset was only seen in the

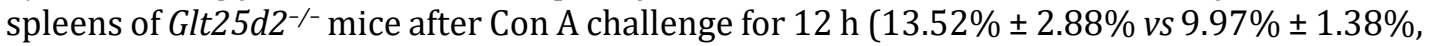
$P=0.007)$ and $24 \mathrm{~h}(15.90 \% \pm 3.26 \%$ vs $7.60 \% \pm 2.94 \%, P=0.0009)$; the frequency of the 


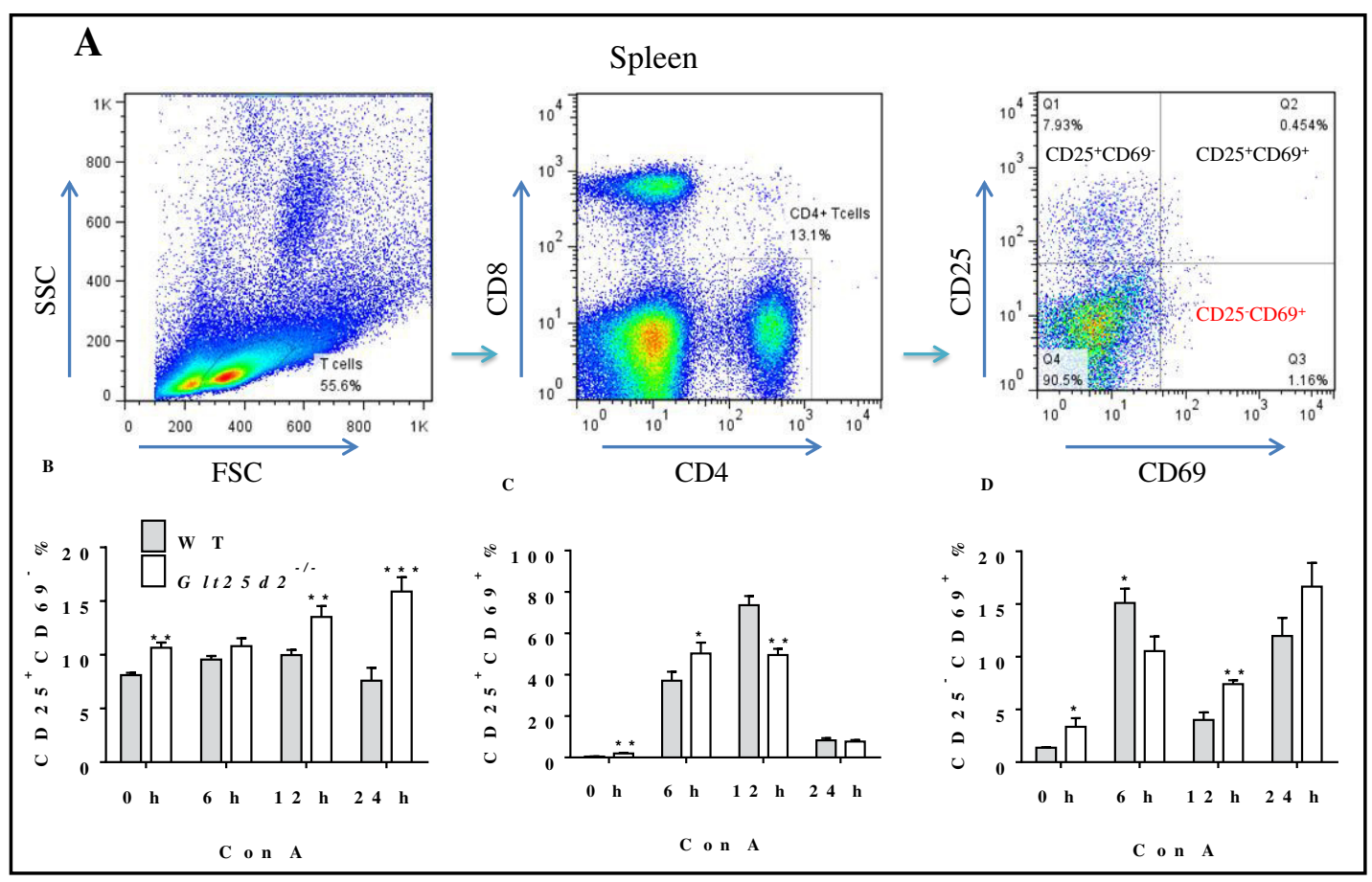

Fig. 6. Phenotype analysis of spleen subsets of $\mathrm{CD} 4^{+} \mathrm{T}$ cells. A, Gating method used to identify $\mathrm{CD} 4^{+} \mathrm{T}$ cells and their subsets. B-D, The column diagram shows $\mathrm{CD} 25^{+} \mathrm{CD} 69^{-}(\mathrm{B}), \mathrm{CD}^{2} 5^{+} \mathrm{CD} 69^{+}(\mathrm{C})$, and $\mathrm{CD}^{-} 5^{-} \mathrm{CD} 69^{+}$ (D) subsets of $C D 4^{+} \mathrm{T}$ cells in the spleen before versus after concanavalin A challenge for $0,6,12$, or $24 \mathrm{~h}$ $\left({ }^{*} \mathrm{P}<0.05 ;{ }^{*} \mathrm{P}<0.001 ;{ }^{* *} \mathrm{P}<0.0001\right)$.

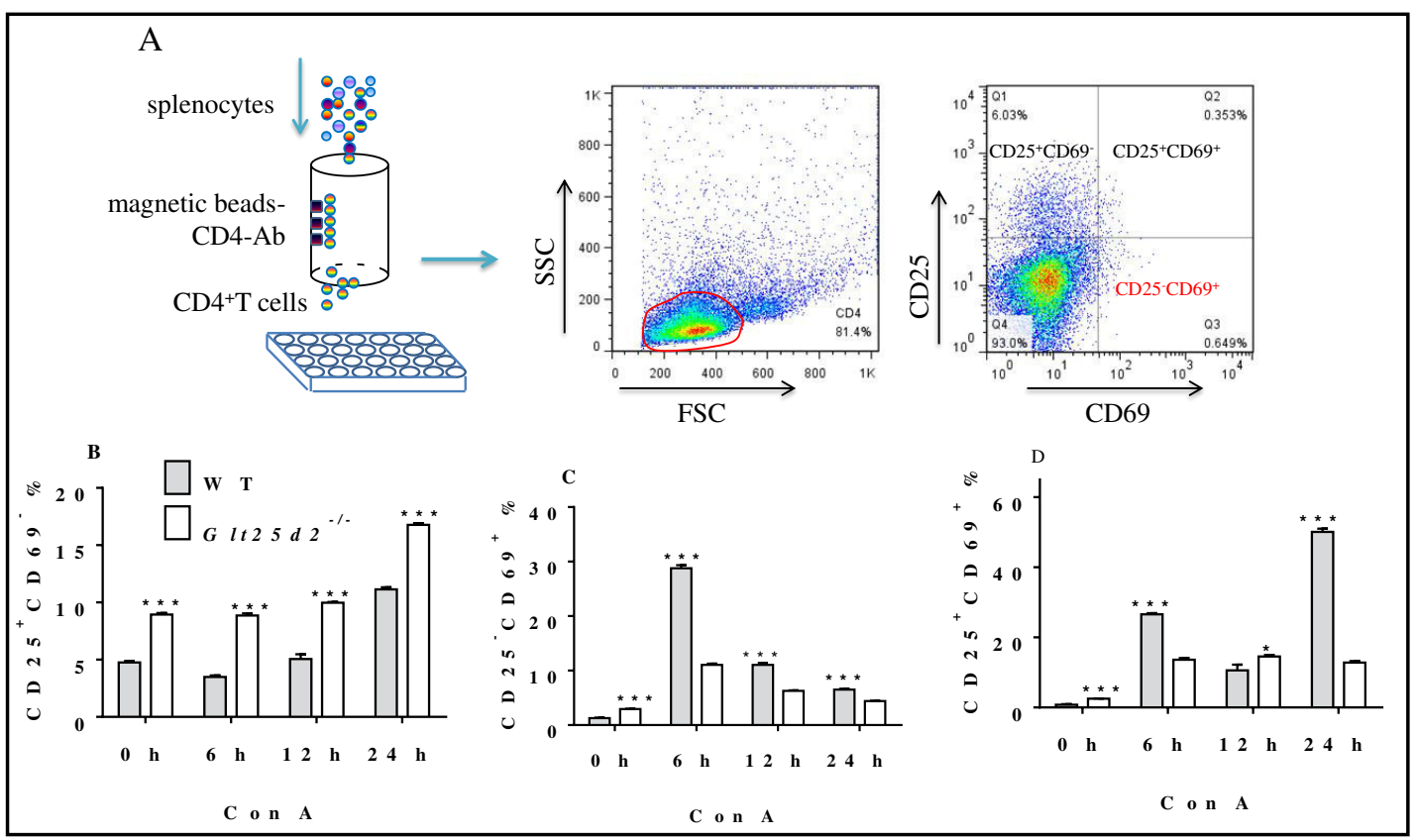

Fig. 7. Phenotype analysis of primary $\mathrm{CD} 4^{+} \mathrm{T}$ cells isolated from splenocytes (ex vivo). A, Primary $\mathrm{CD} 4^{+} \mathrm{T}$ cells isolated from splenocytes were analyzed before and after concanavalin A (Con A) challenge for 0, 6, 12, or 24 h. B-D, The column diagram shows CD25+CD69- (B), CD25+CD69+ (C), and CD25-CD69+ (D) subsets of $\mathrm{CD}^{+} \mathrm{T}$ cells in the spleen before versus after Con $\mathrm{A}$ challenge for $0,6,12$, or $24 \mathrm{~h}\left({ }^{*} \mathrm{P}<0.05\right.$; ${ }^{*} \mathrm{P}<0.001$; $* * * \mathrm{P}<0.0001)$. 


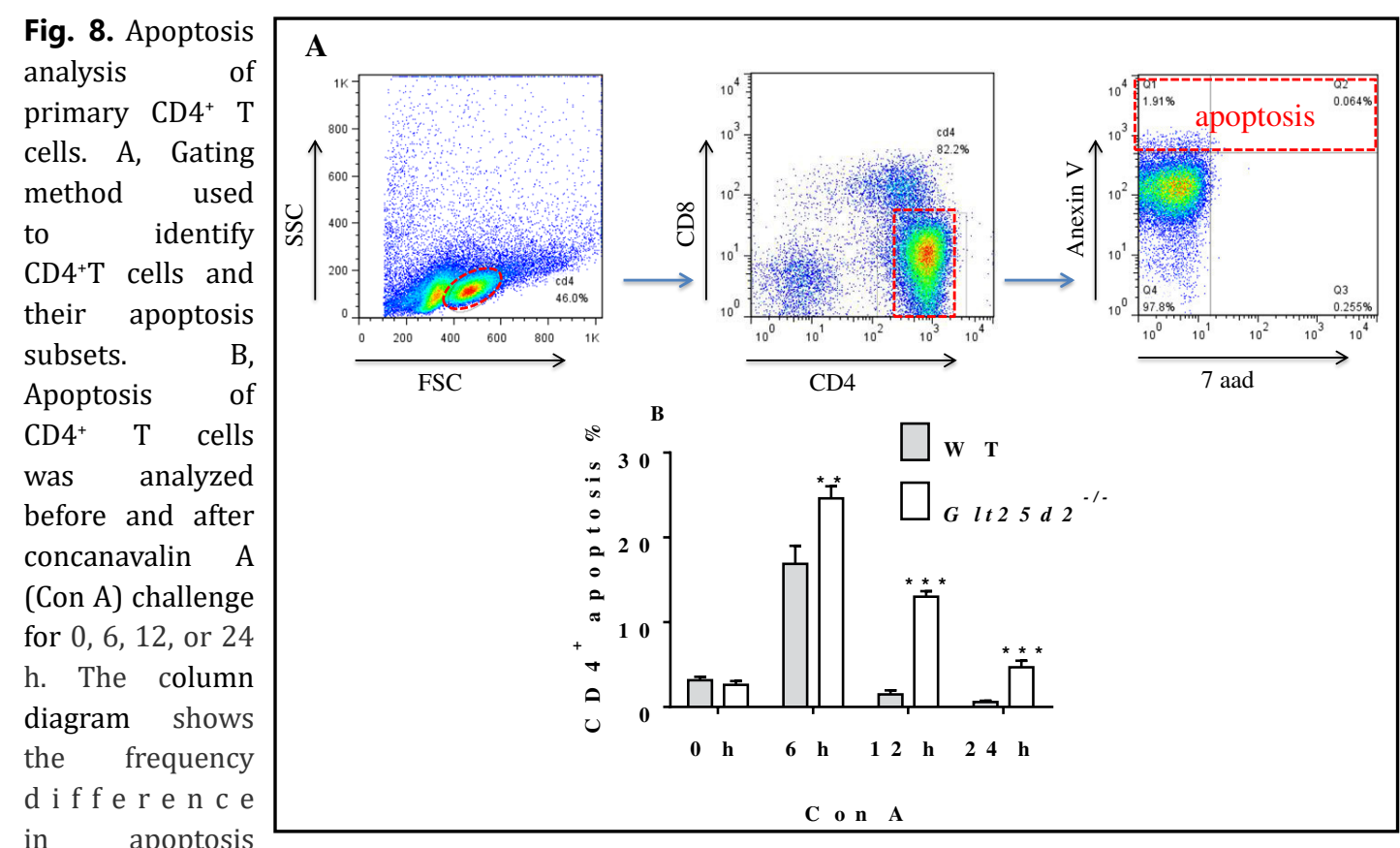

between wild-

type (WT) and Glt25 $\mathrm{d}^{-/-} \mathrm{CD} 4^{+} \mathrm{T}$ cells before and after Con A challenge for $0,6,12$, or $24 \mathrm{~h}\left({ }^{*} \mathrm{P}<0.01\right.$; $* * * \mathrm{P}<0.0001)$.

CD25-CD69+ ${ }^{+}$subset in splenocytes was significantly increased after Con A challenge for $12 \mathrm{~h}$ $(7.41 \% \pm 0.96 \%$ vs $4.00 \% \pm 2.02 \%, P=0.001)$ compared with those in WT mice (Fig. 6). The other notable result was that the subset frequency of $\mathrm{Glt}_{2} 5 \mathrm{~d} 2^{-{ }_{-}} \mathrm{CD} 4^{+} \mathrm{T}$ cells was significantly different from that in WT CD4 ${ }^{+} \mathrm{T}$ cells at baseline (before Con A challenge).

Glt25d2 knockout increased frequency of the $C D 25^{+} C D 69^{-}$subset but decreased frequency of the $C D 25^{-} \mathrm{CD} 69^{+}$subset in primary $C D 4^{+} \mathrm{T}$ cells

To further define the functional role of GLT25D2 in Con A-induced hepatitis, the CD4 ${ }^{+}$ $\mathrm{T}$ cells were isolated from splenocytes and challenged with Con $\mathrm{A}(5 \mu \mathrm{g} / \mathrm{mL})$ for $0,6,12$, or $24 \mathrm{~h}$. The frequency of the $\mathrm{CD} 25^{+} \mathrm{CD} 69^{-}$subset was significantly increased in Glt25d2-/- $\mathrm{CD} 4^{+}$ T cells after Con A challenge for $0 \mathrm{~h}(8.94 \% \pm 0.37 \%$ vs $4.75 \% \pm 0.38 \%, P<0.0001), 6 \mathrm{~h}$ $(8.85 \% \pm 0.56 \%$ vs $3.49 \% \pm 0.36 \%, P<0.0001), 12 \mathrm{~h}(9.97 \% \pm 0.19 \%$ vs $5.05 \% \pm 1.13 \%, P<$ $0.0001)$, or $24 \mathrm{~h}(16.78 \% \pm 0.41 \%$ vs $11.14 \% \pm 0.47 \%, P<0.0001)$ compared with those in WT CD4 ${ }^{+} \mathrm{T}$ cells. However, the frequency of the $\mathrm{CD} 25^{-} \mathrm{CD} 69^{+}$subset was markedly decreased in Glt25 $\mathrm{d}^{-/-} \mathrm{CD}^{+} \mathrm{T}$ cells after Con A challenge for $6 \mathrm{~h}(11.04 \% \pm 0.69 \%$ vs $28.77 \% \pm 1.56 \%$, $P<0.0001), 12 \mathrm{~h}(6.27 \% \pm 0.27 \%$ vs $11.05 \% \pm 0.96 \%, P<0.0001)$, or $24 \mathrm{~h}(4.42 \% \pm 0.20 \%$ vs $6.50 \% \pm 0.44 \%, P<0.0001$ ) compared with those in WT CD $4^{+}$T cells (Fig. 7).

\section{Activation-induced apoptosis increased in Glt25d2-- $C D 4^{+}$T cells}

Since the proper function of T lymphocytes is correlated with glycosylation status, we also determined whether the apoptosis of $\mathrm{CD}^{+} \mathrm{T}$ cells changed after Glt25d2 knockout. We observed the apoptosis rate of primary CD4+ $\mathrm{T}$ cells from WT and Glt25d2/-- mice after challenge with Con A ( $5 \mu \mathrm{g} / \mathrm{mL})$ for $0,6,12$, or $24 \mathrm{~h}$. Subsequently, the cells were stained with fluorescently tagged annexin $\mathrm{V}$ antibody and 7-AAD. As expected, the activation-

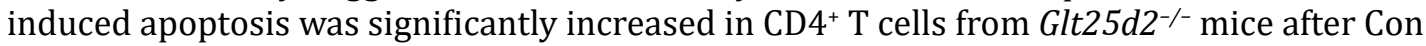
A challenge for $6 \mathrm{~h}(24.62 \% \pm 4.00 \%$ vs $16.88 \% \pm 5.65 \%, P=0.0085), 12 \mathrm{~h}(13.02 \% \pm 1.60 \%$ vs $1.49 \% \pm 1.24 \%, P<0.0001)$, and $24 \mathrm{~h}(4.70 \% \pm 1.86 \%$ vs $0.59 \% \pm 0.42 \%, P<0.0001)$ compared with those in $\mathrm{CD}^{+}{ }^{+}$cells from WT mice (Fig. 8). 


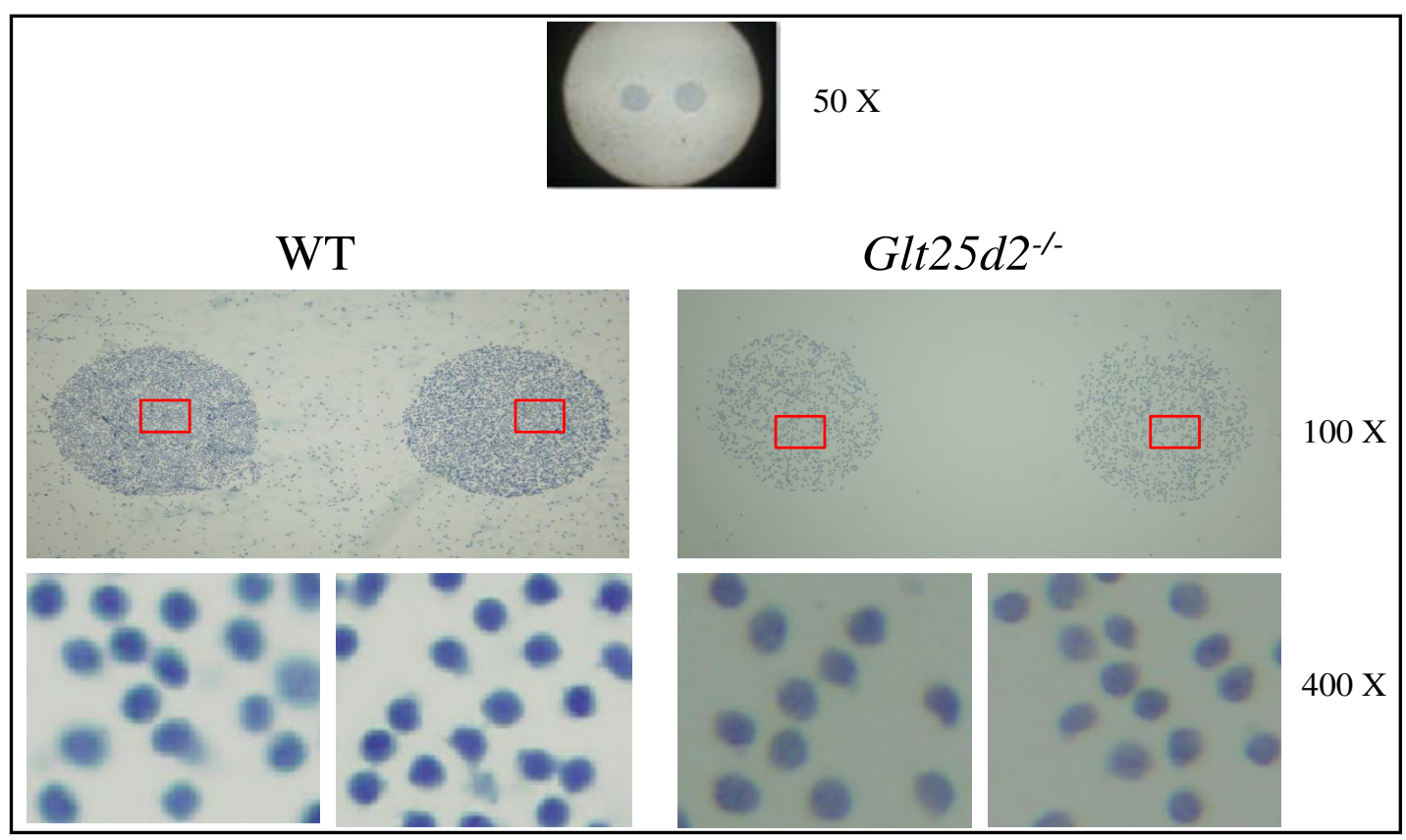

Fig. 9. Lectin array analysis of $\mathrm{CD}^{+} \mathrm{T}$ cells. To test the surface glycan repertoires between wild-type (WT) and Glt25 $\mathrm{d}^{-/-} \mathrm{CD} 4^{+} \mathrm{T}$ cells, the lectin array was used to determine the lectin-binding signatures. After isolation by magnetic beads labeled with CD4 monoclonal antibody and challenge with concanavalin A for 6, 12 , or $24 \mathrm{~h}, \mathrm{CD}^{+} \mathrm{T}$ cells were harvested and then incubated on a lectin array at $37^{\circ} \mathrm{C}$ for $1 \mathrm{~h}$. Hematoxylin and eosin staining was performed after three phosphate buffered saline washes. The lectin-binding signature was observed by microscopy. ACL staining of WT CD4+ T cells and WFL staining of Glt25d2-/- CD4+ T cells are shown here.

Lectin-binding signature for $C D 4^{+} T$ cells during Con A challenge

The lectin-binding signature was determined to characterize the differences in cell surface glycan repertoires between WT and Glt25d2-/$\mathrm{CD}^{+} \mathrm{T}$ cells (Fig. 9). Glt25d2 knockout significantly Table 2. Lectin-binding signature of wild type (WT) and Colgalt $2 \%$ CD4+T cells

\begin{tabular}{lcccccccc}
\hline & \multicolumn{2}{c}{ Control } & \multicolumn{2}{c}{ Con A 6 h } & \multicolumn{2}{c}{ Con A 12 h } & \multicolumn{2}{c}{ Con A 24 h } \\
& WT & Colgalt2 $\%$ & WT & Colgalt2 $\%$ & WT & Colgalt2 $\%$ & WT & Colgalt2 $\%$ \\
\hline MPL & + & - & - & + & - & - & - & - \\
ECA & + & - & - & - & - & - & + & - \\
WFA & - & + & - & - & - & - & - & - \\
HHL & - & + & + & + & + & + & + & + \\
WGA & - & + & - & - & - & - & + & - \\
GNL & - & + & + & + & + & + & + & + \\
NPL & - & + & - & + & - & - & - & + \\
SBA & + & + & + & + & + & - & + & + \\
MAL-I & + & + & - & - & - & - & - & - \\
ACL & + & + & + & - & + & - & + & - \\
Jacalin & + & + & - & + & + & + & + & - \\
\hline
\end{tabular}
increased the binding activities of several lectins. The Wisteria floribunda lectin (WFL)-, hippeastrum hybrid lectin (HHL)-, wheat germ agglutinin, Galanthus nivalis lectin (GNL)-, and Narcissus pseudonarcissus leptin (NPL)-binding activities were only observed in Glt25 $\mathrm{d}^{-/-} \mathrm{CD} 4^{+} \mathrm{T}$ cells; in contrast, the MPLand Erythrina cristagalli lectin (ECA)-binding activities were found only in WT CD4 ${ }^{+} \mathrm{T}$ cells. Glt25d2 knockout seemed to have no significant effect on the binding activities of soybean agglutinin lectin, Maackia amurensis leucoagglutinin 1 (MAL1), Amaranthus caudatus lectin (ACL), or jackfruit lectin of CD4 ${ }^{+} \mathrm{T}$ cells under normal conditions (Table 2).

Since glycoform reconstruction occurs during $\mathrm{T}$ lymphocyte activation, we also determined the surface glycoform variation of $\mathrm{CD}^{+} \mathrm{T}$ cells for Con A-induced activation at 6,12 , and $24 \mathrm{~h}$. Table 2 shows that Glt25d2 knockout increased binding of NPL to CD4 ${ }^{+} \mathrm{T}$ cells, whereas ACL-binding activity was lost. The binding activities of several lectins, namely, MAL1, WFA, MPL, and ECA, were lost during Con A stimulation, whereas those of HHL and GNL were increased irrespective of CD4+ $\mathrm{T}$ cell genotype (WT vs Glt25d2/-) (Table 2).

\section{KARGER}




\section{Cellular Physiology Cell Physiol Biochem 2018;50:1186-1200

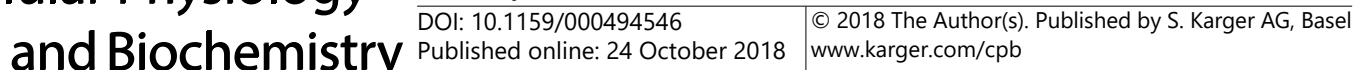

Hao et al.: Glt25d2 Regulating CD4 ${ }^{+}$T Subset Proliferation

\section{Discussion}

Collagen structure is critical to $\mathrm{CD}^{+} \mathrm{T}$ cell regulation [37], but the effect of collagen

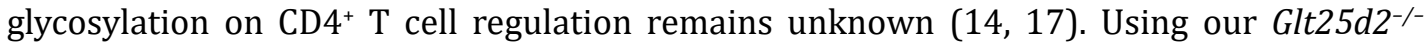
mouse model, we found that Glt25d2 knockout regulated the frequency of CD4 $4^{+} \mathrm{T}$ cell subsets involved in Con A-induced hepatitis.

Glycosylation of the collagen protein was discovered nearly 60 years ago (10), and only recently were three gene products considered candidate glycosyltransferases, namely, lysyl hydroxylase 3 (12), GLT25D1, and GLT25D2 [13, 38, 39]. In one of these studies, GLT25D2 was shown to mediate Glc $\alpha 1,2 \mathrm{Gal} \beta 1$ glycosylation of hydroxylysine in collagen proteins (13). Using our Glt25d2 ${ }^{--}$mouse model, we found that Glt25d2 knockout directly aggravated liver injury and increased the inflammatory response after Con A challenge. Based on the present data and recent results, IL-4, IL-6, IL-1 $\beta$, and IL-9 may complicate this process [40, 41]. Some chemokines, such as MIP-2, eotaxin, and GRO $\alpha$, were also significantly increased in Glt25d2-/mice after Con A challenge compared with those in WT mice. The above results suggested that Glt25d2 knockout may result in an abnormal chemotactic response to inflammatory cells.

Based on a recent report, GLT25D2 is a glycotransferase that mediates Glc $\alpha 1,2 \mathrm{Gal} \beta 1$ glycosylation of hydroxylysine in collagen and is involved in collagenous fibrils assembling into collagen fibers [13]. Since many proteins contain collagen domains and are involved in $\mathrm{T}$ cell regulation, as recent reports stated [42], we considered that GLT25D2 could mediate Glc $\alpha 1,2 \mathrm{Gal} \beta 1$ glycosylation of other collagen-like proteins in primary CD4+ $\mathrm{T}$ cells in vitro and play a role in $\mathrm{CD} 4^{+} \mathrm{T}$ cell regulatory processes such as proliferation and apoptosis. $\mathrm{CD} 4^{+} \mathrm{CD} 25^{-}$ $\mathrm{CD}^{2} 9^{+} \mathrm{T}$ cells are a novel subset of regulatory $\mathrm{T}$ cells that suppress $\mathrm{T}$ cell proliferation [43] and play a role in anti-graft-versus-host disease in humans [44]. We recently also found that the $\mathrm{CD}^{2} 5^{-} \mathrm{CD} 69^{+}$subset of $\mathrm{CD} 4^{+} \mathrm{T}$ cells is also involved in Con A-induced hepatitis [45]. To put our data in a wider context, the relative decrease in the $\mathrm{CD} 25^{-} \mathrm{CD} 69^{+}$subset suggested that the $\mathrm{CD} 4^{+}$regulatory T cells may be partly suppressed in $\mathrm{Glt} 25 \mathrm{d2^{-/- }}$ mice.

Our present results demonstrate for the first time that glycosylation mediated by GLT25D2 regulates the subset frequency of $\mathrm{CD}^{+}{ }^{+} \mathrm{T}$ cells. However, the molecular mechanisms of how surface glycoform changes influence the subset differentiation of $\mathrm{CD} 4^{+} \mathrm{T}$ cells requires elucidation. As shown in a previous report [35] and confirmed here, altering cell surface glycan repertoires leads to different subset differentiation of $\mathrm{CD} 4^{+} \mathrm{T}$ cells. Different from hyposialylation $\left(\mathrm{Cmah}^{-/}\right.$mice) leading to T lymphocyte proliferation and activation [46], inhibiting Glc $\alpha 1,2 \mathrm{Gal} \beta 1$ glycosylation (Glt25 $2^{-/-}$mice) resulted in a different subset of CD $4^{+}$ T cells. As described above, many cell surface proteins may also be targets of GLT25D2 since they contain a collagen domain, such as mannan-binding lectin, which directly regulates $\mathrm{T}$ cell proliferation [47]. Therefore, we speculated that the differences in the lectin-binding signature resulted from the Glt25d2 knockout in vitro. Glt25d2 knockout increased the binding activity of NPL to CD4 ${ }^{+} \mathrm{T}$ cells, whereas ACL-binding activity was lost. This result suggests that other receptor substrates of GLT25D2 may exist in CD4 ${ }^{+} \mathrm{T}$ cells since NPL and ACL mainly recognize the terminal mannose Gal $\beta 1$, 3GalNAc of cell surface glycans.

In contrast to findings of a previous study in human tissue [21], the present data show that GLT25D2 is broadly expressed in the spleen, thymus, and other tissues of mice. This expression difference may be due to species differences. The major limitation of the present study is that all the data are based on primary CD $4^{+} \mathrm{T}$ cells in vitro. Glt25d2 knockout may lead to more complicated subset differentiation of $\mathrm{CD} 4^{+} \mathrm{T}$ cells in vivo. Based on a recent report, GLT25D1 may partly play a compensatory role in collagen glycosylation after Glt25d2 knockout [48]. The exact role of Glc $\alpha 1,2 \mathrm{Gal} \beta 1$ glycosylation in collagen secretion and CD $4^{+}$ $\mathrm{T}$ differentiation remains to be clarified.

Since the collagen glycosylation mediated by GLT25D2 (and GLT25D1) is initiated in the ER, we speculated that CD $4^{+}$T cell regulation by GLT25D2 may be via two major pathways: (i) 
directly modifying collagen and influencing ECM structure; and (ii) modifying some proteins containing collagen domains that are located on the surface of $\mathrm{CD}^{+} \mathrm{T}$ cells, such as $\mathrm{C}$-type lectins [49], playing a very important indirect role in $\mathrm{CD} 4^{+} \mathrm{T}$ cell regulation.

The present results suggest that collagen glycosylation mediated by GLT25D2 may be involved in regulating proliferation of $\mathrm{CD} 4^{+} \mathrm{T}$ cell subsets and correlated with the pathogenesis of immune hepatitis. Collagen Glc $\alpha 1,2 \mathrm{Gal} \beta 1$ glycosylation mediated by GLT25D2 may be a new target of drug development for immune regulation and protection against liver injury.

\section{Abbreviations}

$\mathrm{Ab}$ (antibody); WT (wild type); MPL (maclura pomifera lectin); ECA (erythrina cristagalli lectin); WFA (wisteria floribunda lectin); HHL (hippeastrum Hybrid lectin); WGA (wheat germ agglutinin); GNL (galanthus nivalis lectin); NPL (narcissus pseudonarcissus lectin); SBA (glycine Max lectin); MAL-I (maackia amurensis lectin I); ACL (axinella corrugata).

\section{Acknowledgements}

This work was supported by grants from the National Natural Science Foundation of China (NNSFC 30872243 and NNSFC 81271901); Natural Science Foundation of Beijing (7152073) (to Prof. H.Wei); and NNSFC 20672144 (to Prof Q. He).

\section{Disclosure Statement}

The authors declare no competing financial interests.

\section{References}

1 Khokha R, Murthy A, Weiss A: Metalloproteinases and their natural inhibitors in inflammation and immunity. Nat Rev Immunol 2013;13:649-665.

- Hallmann R, Zhang X, Di Russo J, Li L, Song J, Hannocks MJ, Sorokin L: The regulation of immune cell trafficking by the extracellular matrix. Curr Opin Cell Biol 2015;36:54-61.

-3 Brown FD, Turley SJ: Fibroblastic reticular cells: organization and regulation of the T lymphocyte life cycle. J Immunol 2015;194:1389-1394.

4 Frey H, Schroeder N, Manon-Jensen T, Iozzo RV, Schaefer L: Biological interplay between proteoglycans and their innate immune receptors in inflammation. Febs J 2013;280:2165-2179.

-5 Nastase MV, Young MF, Schaefer L: Biglycan: a multivalent proteoglycan providing structure and signals. The journal of histochemistry and cytochemistry :J Histochem Cytochem 2012;60:963-975.

6 Nickmann M, Saemisch M, Wilbert-Lampen U, Nickel T, Edelman ER, Methe H: Cell matrix contact modifies endothelial major histocompatibility complex class II expression in high-glucose environment. Am J Physiol Heart Circ Physiol 2013;305:H1592-1599.

7 Jobling R, D’Souza R, Baker N, Lara-Corrales I, Mendoza-Londono R, Dupuis L, Savarirayan R, Ala-Kokko L, Kannu P: The collagenopathies: review of clinical phenotypes and molecular correlations. Curr Rheumatol Rep 2014;16:394.

$>8$ Mienaltowski MJ, Birk DE: Structure, physiology, and biochemistry of collagens. Adv Exp Med Biol 2014;802:5-29.

-9 Ishikawa Y, Bachinger HP: A molecular ensemble in the rER for procollagen maturation. Biochim Biophys Acta 2013;1833:2479-2491.

10 Rosenbloom J, Blumenkrantz N, Prockop DJ: Sequential hydroxylation of lysine and glycosylation of hydroxylysine during the biosynthesis of collagen in isolated cartilage. Biochem Biophys Res Commun 1968;31:792-797. 


\section{Cellular Physiology Cell Physiol Biochem 2018;50:1186-1200 \begin{tabular}{l|l|l} 
and Biochemistry & $\begin{array}{l}\text { DOI: 10.1159/000494546 } \\
\text { Published online: 24 October } 2018\end{array}$ & $\begin{array}{l}\text { @ 2018 The Author(s). Published by S. Karger AG, Basel } \\
\text { www.karger.com/cpb }\end{array}$
\end{tabular}}

Hao et al.: Glt25d2 Regulating CD4 ${ }^{+} \mathrm{T}$ Subset Proliferation

11 Spiro RG, Lucas F, Rudall KM: Glycosylation of hydroxylysine in collagens. Nat New biol 1971;231:54-55.

12 Wang C, Luosujarvi H, Heikkinen J, Risteli M, Uitto L, Myllyla R: The third activity for lysyl hydroxylase 3: galactosylation of hydroxylysyl residues in collagens in vitro. Matrix Biol 2002;21:559-566.

$\$ 13$ Schegg B, Hülsmeier AJ, Rutschmann C, Maag C, Hennet T: Core glycosylation of collagen is initiated by two beta(1-0)galactosyltransferases. Mol Cell Biol 2009;29:943.

14 Gorgun G, Anderson KC: Intrinsic modulation of lymphocyte function by stromal cell network: advance in therapeutic targeting of cancer. Immunotherapy 2011;3:1253-1264.

15 Rommerswinkel N, Niggemann B, Keil S, Zänker K, Dittmar T: Analysis of cell migration within a threedimensional collagen matrix. J Vis Exp 2014:e51963.

-16 Popovic ZV, Wang S, Papatriantafyllou M, Kaya Z, Porubsky S, Meisner M, Bonrouhi M, Burgdorf S, Young MF, Schaefer L, Grone HJ: The proteoglycan biglycan enhances antigen-specific T cell activation potentially via MyD88 and TRIF pathways and triggers autoimmune perimyocarditis. J Immunol 2011;187:62176226.

17 Fulop T, Khalil A, Larbi A: The role of elastin peptides in modulating the immune response in aging and agerelated diseases. Patho Biol 2012;60:28-33.

18 Savino W, Smaniotto S, Mendes-da-Cruz DA, Dardenne M: Growth hormone modulates migration of thymocytes and peripheral T cells. Ann N Y Acad Sci 2012;1261:49-54.

19 Warren KJ, Iwami D, Harris DG, Bromberg JS, Burrell BE: Laminins affect T cell trafficking and allograft fate. J Clin Invest 2014;124:2204-2218.

20 Ciechomska M, Wilson CL, Floudas A, Hui W, Rowan AD, van Eden W, Robinson JH, Knight AM: Antigenspecific B lymphocytes acquire proteoglycan aggrecan from cartilage extracellular matrix resulting in antigen presentation and CD4+ T-cell activation. Immunology 2014;141:70-78.

21 Kim CH: Crawling of effector T cells on extracellular matrix: role of integrins in interstitial migration in inflamed tissues. Cell Mol Immunol 2014;11:1-4.

-22 Overstreet MG, Gaylo A, Angermann BR, Hughson A, Hyun YM, Lambert K, Acharya M, Billroth-Maclurg AC, Rosenberg AF, Topham DJ, Yagita H, Kim M, Lacy-Hulbert A, Meier-Schellersheim M, Fowell DJ: Inflammation-induced interstitial migration of effector CD4(+) T cells is dependent on integrin alphaV. $\mathrm{Na}$ Immunol 2013;14:949-958.

23 Loubaki L, Hadj-Salem I, Fakhfakh R, Jacques E, Plante S, Boisvert M, Aoudjit F, Chakir J: Co-culture of human bronchial fibroblasts and CD4+ T cells increases Th17 cytokine signature. PloS One 2013;8:e81983.

24 Pokidysheva E, Zientek KD, Ishikawa Y, Mizuno K, Vranka JA, Montgomery NT, Keene DR, Kawaguchi T, Okuyama K, Bachinger HP: Posttranslational modifications in type I collagen from different tissues extracted from wild type and prolyl 3-hydroxylase 1 null mice. J Biol Chem 2013;288:24742-24752.

25 Terajima M, Perdivara I, Sricholpech M, Deguchi Y, Pleshko N, Tomer KB, Yamauchi M: Glycosylation and cross-linking in bone type I collagen. J Biol Chem 2014;289:22636-22647.

26 Wei H, Li H, Ren H, Hao X, Wang Z, Liu R, Huang Y, Chen L, Wang H, Li B: Preparation and genotyping identification of GLT25D2 knockout mice. Chin J Exp Clin Virol 2013; 27:492-4 (in Chinese).

-27 Heymann F, Hamesch K, Weiskirchen R, Tacke F: The concanavalin A model of acute hepatitis in mice. Lab Anim 2015;49:12-20.

-28 Volarevic V, Misirkic M, Vucicevic L, Paunovic V, Simovic Markovic B, Stojanovic M, Milovanovic M, Jakovljevic V, Micic D, Arsenijevic N, Trajkovic V, Lukic ML: Metformin aggravates immune-mediated liver injury in mice. Arch Toxicol 2015;89:437-450.

-29 Moldenhauer LM, Diener KR, Thring DM, Brown MP, Hayball JD, Robertson SA: Cross-presentation of male seminal fluid antigens elicits $\mathrm{T}$ cell activation to initiate the female immune response to pregnancy. J Immunol 2009;182:8080-8093.

-30 Piccirillo CA, Letterio JJ, Thornton AM, McHugh RS, Mamura M, Mizuhara H, Shevach EM: CD4(+)CD25(+) regulatory T cells can mediate suppressor function in the absence of transforming growth factor beta1 production and responsiveness. J Exp Med 2002;196:237-246.

31 Selvaraj RK: Avian CD4(+)CD25(+) regulatory T cells: properties and therapeutic applications. Dev Comp Immunol 2013;41:397-402.

32 Mani H, Kleiner DE: Liver biopsy findings in chronic hepatitis B. Hepatology 2009;49:S61-71.

-33 Nichols WC, Seligsohn U, Zivelin A, Terry VH, Hertel CE, Wheatley MA, Moussalli MJ, Hauri HP, Ciavarella N, Kaufman RJ, Ginsburg D: Mutations in the ER-Golgi intermediate compartment protein ERGIC-53 cause combined deficiency of coagulation factors V and VIII. Cell 1998;93:61-70. 


\section{Cellular Physiology Cell Physiol Biochem 2018;50:1186-1200 \begin{tabular}{l|l|l} 
DOI: 10.1159/000494546 & $\begin{array}{l}\text { O } 2018 \text { The Author(s). Published by S. Karger AG, Basel } \\
\text { www.karger.com/cpb }\end{array}$
\end{tabular}}

Hao et al.: Glt25d2 Regulating CD4 ${ }^{+} \mathrm{T}$ Subset Proliferation

-34 Hauri HP, Kappeler F, Andersson H, Appenzeller C: ERGIC-53 and traffic in the secretory pathway. J Cell Sci 2000;113:587-596.

35 Shi YQ He Q Zhao YJ, Wang EH, Wu GP: Lectin microarrays differentiate carcinoma cells from reactive mesothelial cells in pleural effusions. Cytotechnology 2013;65:355-362.

-36 Hnatiuk S, Barry M, Zeng W, Liu L, Lucas A, Percy D, McFadden G: Role of the C-terminal RDEL motif of the myxoma virus M-T4 protein in terms of apoptosis regulation and viral pathogenesis. Virology 1999;263:290-306.

-37 Estes JD, Haase AT, Schacker TW: The role of collagen deposition in depleting CD4+ T cells and limiting reconstitution in HIV-1 and SIV infections through damage to the secondary lymphoid organ niche. Semin Immunol 2008;20:181-186.

-38 Spaan Willy JM, Simone P, Liefhebber Jolanda MP, Van LHC: The human collagen beta(1-0) galactosyltransferase, GLT25D1, is a soluble endoplasmic reticulum localized protein. BMC Cell Biol 2010;11:33.

-39 Perrin-Tricaud C, Rutschmann C, Hennet T: Identification of domains and amino acids essential to the collagen galactosyltransferase activity of GLT25D1. PloS One 2011;6:e29390.

40 Luo Q Zhu L, Ding J, Zhuang X, Xu L, Chen F: Protective effect of galangin in Concanavalin A-induced hepatitis in mice. Drug Des Devel Ther 2015;9:2983-2992.

41 Proctor WR, Chakraborty M, Fullerton AM, Korrapati MC, Ryan PM, Semple K, Morrison JC, Berkson JD, Chea LS, Yang Q Li AP, Spolski R, West EE, Rochman Y, Leonard WJ, Bourdi M, Pohl LR: Thymic stromal lymphopoietin and interleukin-4 mediate the pathogenesis of halothane-induced liver injury in mice. Hepatology 2014;60:1741-1752.

42 Li SS, Forslow A, Sundqvist KG: Autocrine regulation of T cell motility by calreticulin-thrombospondin-1 interaction. J Immunol 2005;174:654-661.

43 Han Y, Guo Q Zhang M, Chen Z, Cao X: CD69+ CD4+ CD25- T cells, a new subset of regulatory T cells, suppress T cell proliferation through membrane-bound TGF-beta 1. J Immunol 2009;182:111-120.

44 Lu S, Huang X, Liu K, Liu D, Xu L: High frequency of CD4+ CD25- CD69+ T cells is correlated with a low risk of acute graft-versus-host disease in allotransplants. Clin Transplant 2012;26:E158-167.

45 Yang Q Wang J, Liu R, Wang Z, Li Y, Zhang Y, Hao X, Huang Y, Xie W, Wei H: Amelioration of concanavalin A-induced autoimmune hepatitis by magnesium isoglycyrrhizinate through inhibition of CD4(+)CD25(-) CD69(+) subset proliferation. Drug Des Devel Ther 2016;10:443-453.

46 Buchlis G, Odorizzi P, Soto PC, Pearce OM, Hui DJ, Jordan MS, Varki A, Wherry EJ, High KA: Enhanced T cell function in a mouse model of human glycosylation. J Immunology 2013;191:228-237.

47 Zhao N, Wu J, Xiong S, Zhang L, Lu X, Chen S, Wu Q, Wang H, Liu Y, Chen Z, Zuo D: Mannan-binding lectin, a serum collectin, suppresses T-cell proliferation via direct interaction with cell surface calreticulin and inhibition of proximal T-cell receptor signaling. FASEB J 2017;31:2405-2417.

-48 Baumann S, Hennet T: Collagen Accumulation in Osteosarcoma Cells lacking GLT25D1 Collagen Galactosyltransferase. J Biol Chem 2016;291:18514-18524.

-49 Nabatov AA, de Jong MA, de Witte L, Bulgheresi S, Geijtenbeek TB: C-type lectin Mermaid inhibits dendritic cell mediated HIV-1 transmission to CD4+ T cells. Virology 2008;378:323-328.

-50 Kleiner DE, Brunt EM, Van Natta M, Behling C, Contos MJ, Cummings OW, Ferrell LD, Liu YC, Torbenson MS, Unalp-Arida A, Yeh M, McCullough AJ, Sanyal AJ, Nonalcoholic Steatohepatitis Clinical Research N: Design and validation of a histological scoring system for nonalcoholic fatty liver disease. Hepatology $2005 ; 41: 1313-1321$. 